\title{
Cell Synchrony and Chromosomal Protocols for Somatic Cells of Cotton Gossypium hirsutum
}

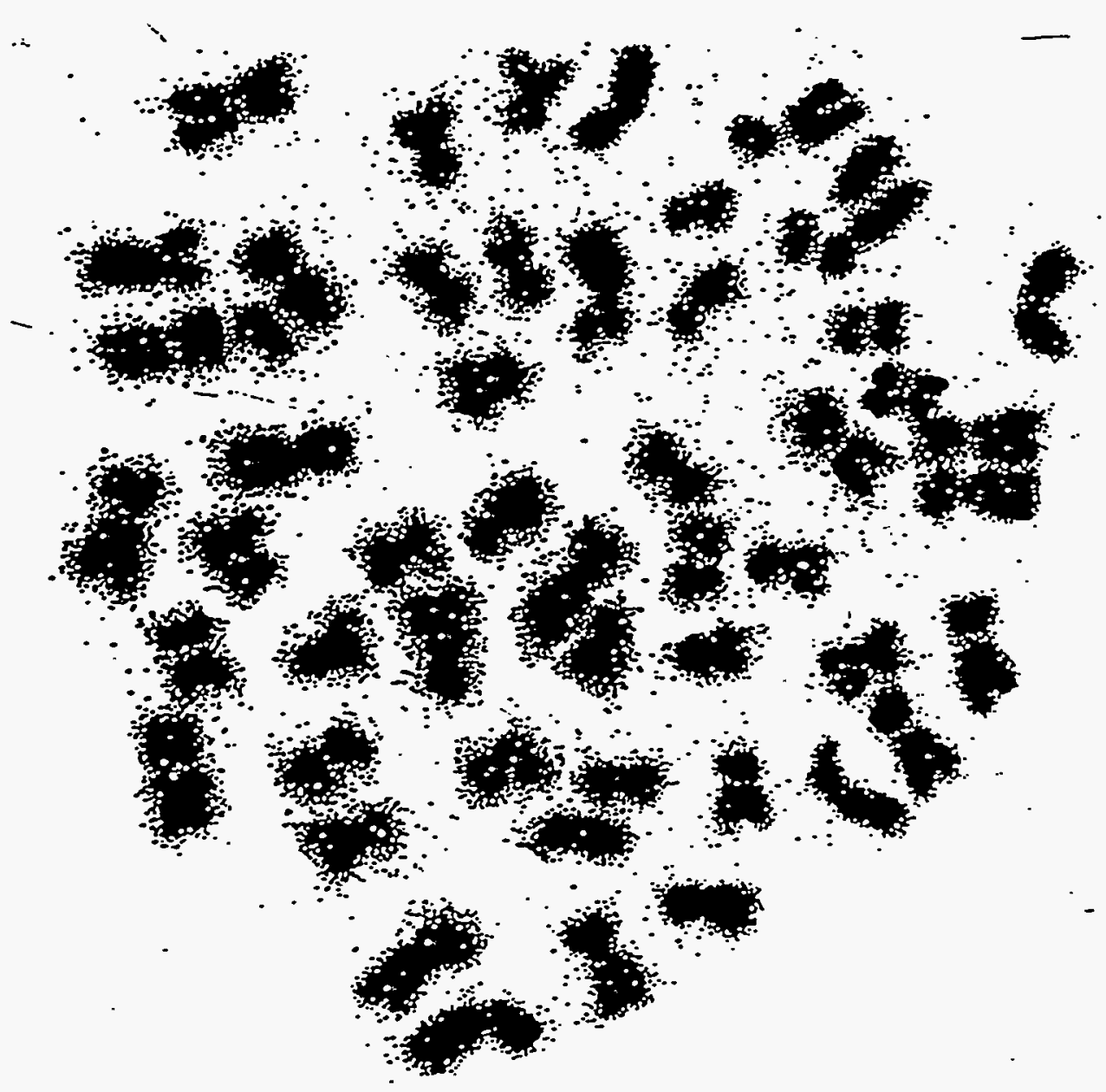

Jack Van't Hof \& Susan S. Lamm Biology Department

Brookhaven National Laboratory October 10, 1994

Work done for U.S. Department of Energy 
Introduction

The intent of this pamphlet is to share information with others who are interested in useful protocols for cotton cytogenetics and cytology. The protocols described are a beginning effort and they are expected to be improved. All methods, results and data given pertain to cultivar MD 51ne (a gift from Hal Lewis, of Scientific Seed, Co.).

We are not satisfied with our results of in situ hybridization. So, view Figure 8, page 15 with this in mind. We seek advice on all aspects of this methodology and will send updated protocols as our technique improves.

This pamphlet will be given a Brookhaven National Laboratory Technical Report number. The number will be sent to you in the future, should you need it for a reference.

Jack Van't Hof

Phone: (516) 282-3419

Fax: (516) 282-3407

E-Mail: vanthofebnluxi.bnl.gov

\section{DISCLAIMER}

This report was prepared as an account of work sponsored by an agency of the United States Government. Neither the United States Government nor any agency thereof, nor any of their employees, makes any warranty, express or implied, or assumes any legal liability or responsibility for the accuracy, completeness, or usefulness of any information, apparatus, product, or process disclosed, or represents that its use would not infringe privately owned rights. Reference herein to any specific commercial product, process, or service by trade name, trademark, manufacturer, or otherwise does not necessarily constitute or imply its endorsement, recommendation, or favoring by the United States Government or any agency thereof. The views and opinions of authors expressed herein do not necessarily state or reflect those of the United States Government or any agency thereof. 


\section{DISCLAIMER}

Portions of this document may be illegible in electronic image products. Images are produced from the best available original document. 
I. Seed Germination

A. Day one

1. cultivar MD 51ne; seed, delinted, stored at $4 \mathrm{C}$

2. rinse seed (about $50 \mathrm{mls}$ worth) in running cold tap water for 6 hours; removal of fungicide \& imbibition

3. rinse seed in $100 \%$ clorox for 1 min with mixing - use fork or spatula to mix

4. rinse seed with running distilled water for $5 \mathrm{~min}$.

5. place 3 layers of whatman no. 1 filter paper (circles, $125 \mathrm{~mm}$ ) in $15 \mathrm{~cm}$ dia. Petri dishes

6. spread 40 to 60 seed on filter paper

7. add $10 \mathrm{ml}$ of deionized water to each dish

8. germinate seed in dark at $26 \mathrm{C}$ for $48 \mathrm{hr}$

B. Day two

Check seed

II. Cell synchronization, 5-aminouracil treatment (day three)

A. in morning suspend seedlings having 2.3 to $2.7 \mathrm{~cm}$ primary roots on plastic mesh over $1 \mathrm{X}$ (full strength) Hoagland's nutrient salt solution, equilibrated to $26 \mathrm{C}$, pH 6 - make sure the primary roots are in the solution

B. place suspended seedlings in incubator at $26 \mathrm{C}$ and aerate with rapid bubbling

C. grow seedlings in the dark for about $10 \mathrm{hr}$

D. at the 10th hour lift seedlings, mesh \& aerator, and suspend roots in $0.8 \mathrm{mg} / \mathrm{ml} 5$-aminouracil (Sigma, A-4005) dissolved in $1 \mathrm{X}$ Hoagland's nutrient solution, $26 \mathrm{C}$ - NOTE: to dissolve 5-aminouracil heat gently with stirring, cool to $26 \mathrm{C}$

E. treat seedlings for $12 \mathrm{hr}$ with 5-aminouracil, $26 \mathrm{C}$, aerated

III. Synchronized cell division, treatment recovery (day four)

A. after treatment lift seedlings, mesh and aerator rinse with distilled water, $26 \mathrm{C}$, then suspend seedlings in fresh $1 \mathrm{X}$ Hoagland's nutrient solution, $26 \mathrm{C}$, return to chamber for recovery in the dark with aeration

B. root meristematic cells will divide synchronously between 3 and $6 \mathrm{hr}$ (Figures $1 \& 2$ ); do not expect $100 \%$; see ref. 4.

c. fix root tips with ice-cold 3 parts methanol

and 1 part glacial acetic acid; select those that grew 1 $\mathrm{cm}$, are cream-colored, \& thin

D. after $10 \mathrm{~min}$, remove fix and add fresh fix

E. store at $-20 \mathrm{C}$ 


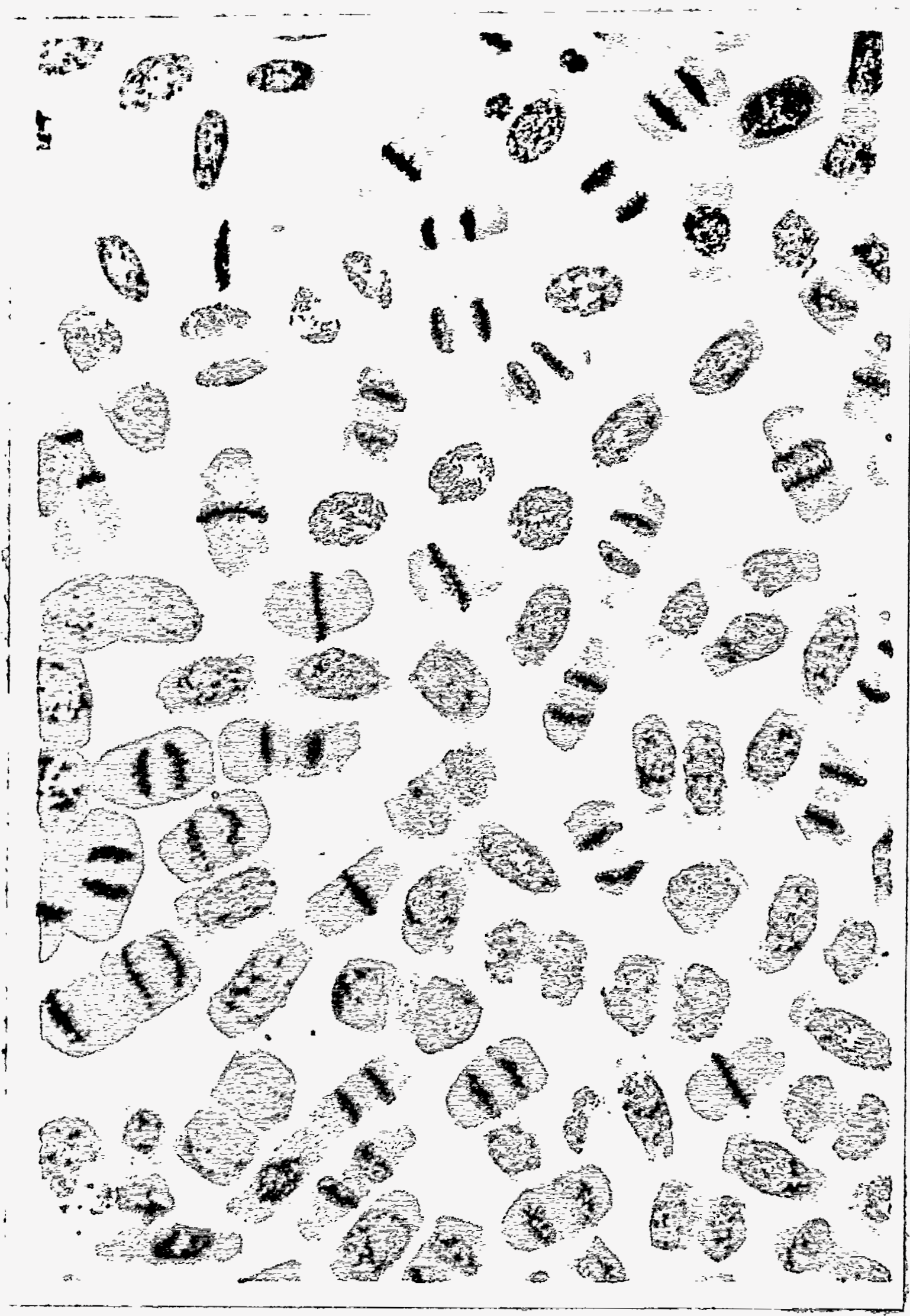

Figure 1. Synchronized cell division 5 hours after 5-aminouracil treatment; squash preparation. 
IV. Accumulation of metaphase cells with cycloheximide (Sigma c6255; CalBiochem, actidione=cycloheximide)

A. at 3.5 to 4 hours after removal of 5-aminouracil transfer seedlings to $1 \mathrm{X}$ Hoagland's nutrient solution, $26 \mathrm{c}, \mathrm{pH} 6$, containing $10 \mathrm{ug} / \mathrm{ml}$ of cycloheximide; return to incubator and aerate

B. treat for 2 hours

C. fix root tips as described in III above

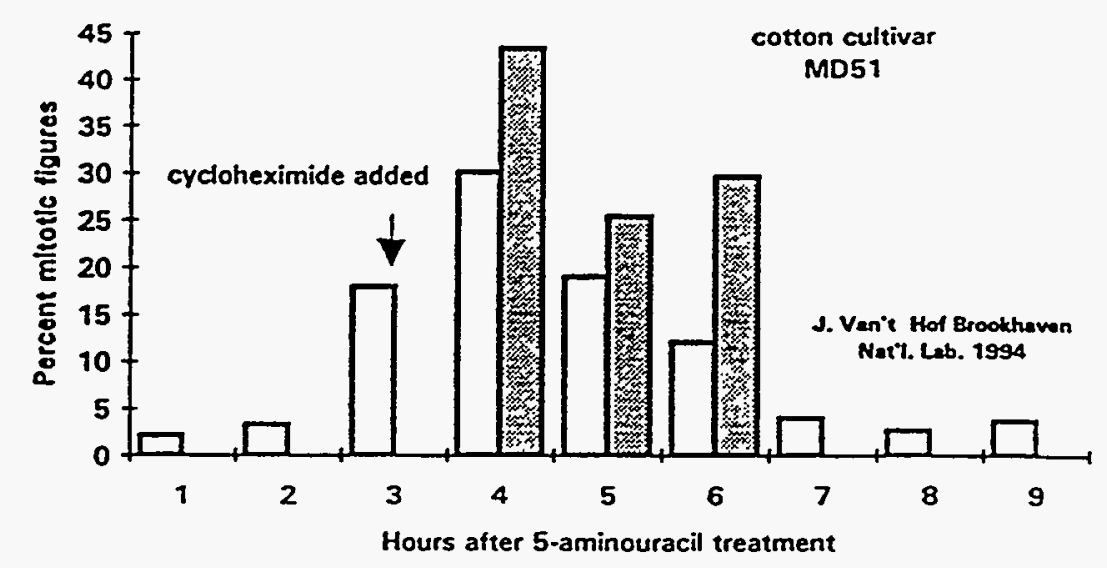

Figure 2. Percent mitotic figures expressed as a function of time after ending 5-aminouracil treatment. Open bars - no cycloheximide added; stippled bars - $10 \mathrm{ug} / \mathrm{ml}$ cycloheximide treatment beginning at 3.5 hours. Squash preparations; combined data from three experiments.

V. Feulgen stained chromosomes

A. Feulgen staining:

1. remove root tips from $f i x$

2. suspend in deionized water until they sink

3. cut off $3-4 \mathrm{~mm}$ tips

4. suspend tips in deionized water in $1.5 \mathrm{ml}$ Eppendorf tube

5. spin in microfuge for a couple of seconds

6. remove water and add fresh water

7. spin again in microfuge

8. repeat wash-spin twice

9. remove water 
10. add $5 \mathrm{~N} \mathrm{HCl,} \mathrm{about} 200 \mathrm{ul}$

11. leave in $\mathrm{HCl}$ for $30-45 \mathrm{~min}$ at room temp.

12. spin in microfuge

13. remove $\mathrm{HCl}$

14. wash with deionized water \& spin, repeat three (3) times

15. remove water \& add about 200 ul of room-temp schiff's reagent

16. let stain for about 1 hour; root tips should turn pink in $10 \mathrm{~min}$

17. remove Schiff's reagent

18. wash with deionized water and spin, repeat three times

B. Cell separation after staining

1. remove water

2. add $200 \mathrm{ul}$ of enzyme $\mathrm{mix}(0.01 \mathrm{gm}$ of $3: 1: 1 \mathrm{mix}$ in 200 ul water)

- dry enzyme mix is:

3 parts cellulysin

1 part hemicellulase

1 part pectolyase

cellulysin [Calbiochem]

hemicellulase [Sigma]

pectolyase [Seishin]

3. digest for $30 \mathrm{~min}$ at room temp.

4. break-up root tips first by crushing with micropipet tip, then by drawing up into the pipet tip itself

5. continue digestion for another $30 \mathrm{~min}$

6. spin at $1000 \mathrm{rpm}(200 \times \mathrm{g})$ in $\mathrm{TJ}-6$ swinging-bucket centrifuge for $1-2 \mathrm{~min}$

- can use any low speed swinging-bucket head

7. remove enzyme mix

8. add $200 \mathrm{ul}$ deionized water \& gently mix by tilting tube

9. spin at $1000 \mathrm{rpm}, 1-2 \mathrm{~min}$

10. repeat 8 \& 9 above

11. remove water above pellet leaving about 5 ul behind (amount of water left behind depends on the size of the pellet)

12. store on ice

13. clean microscope slide with $100 \%$ ETOH until it squeaks

14. gently suspend cells in pellet 
15. remove about $0.5-1.0$ ul of cell suspension with micropipet

16. place in center of cleaned slide equal distance from the edge of the frosted end and the unfrosted end

17. remove about 5 ul of ice-cold fix $(3: 1)$

18. drop the ice-cold 3:1 fix on top of the droplet of suspended cells

- the action of the fix will spread the cells on the slide's surface

19. air dry

20. add a drop of $100 \%$ glycerol to center of spread

21. place coverslip over drop and remove excess glycerol by blotting

22. view chromosomes by either bright field or fluorescence microscopy

a. Figure 3 Feulgen fluorescence, page 8

b. Figures 4 and 5, page 9, measurements from cell in Figure 3 


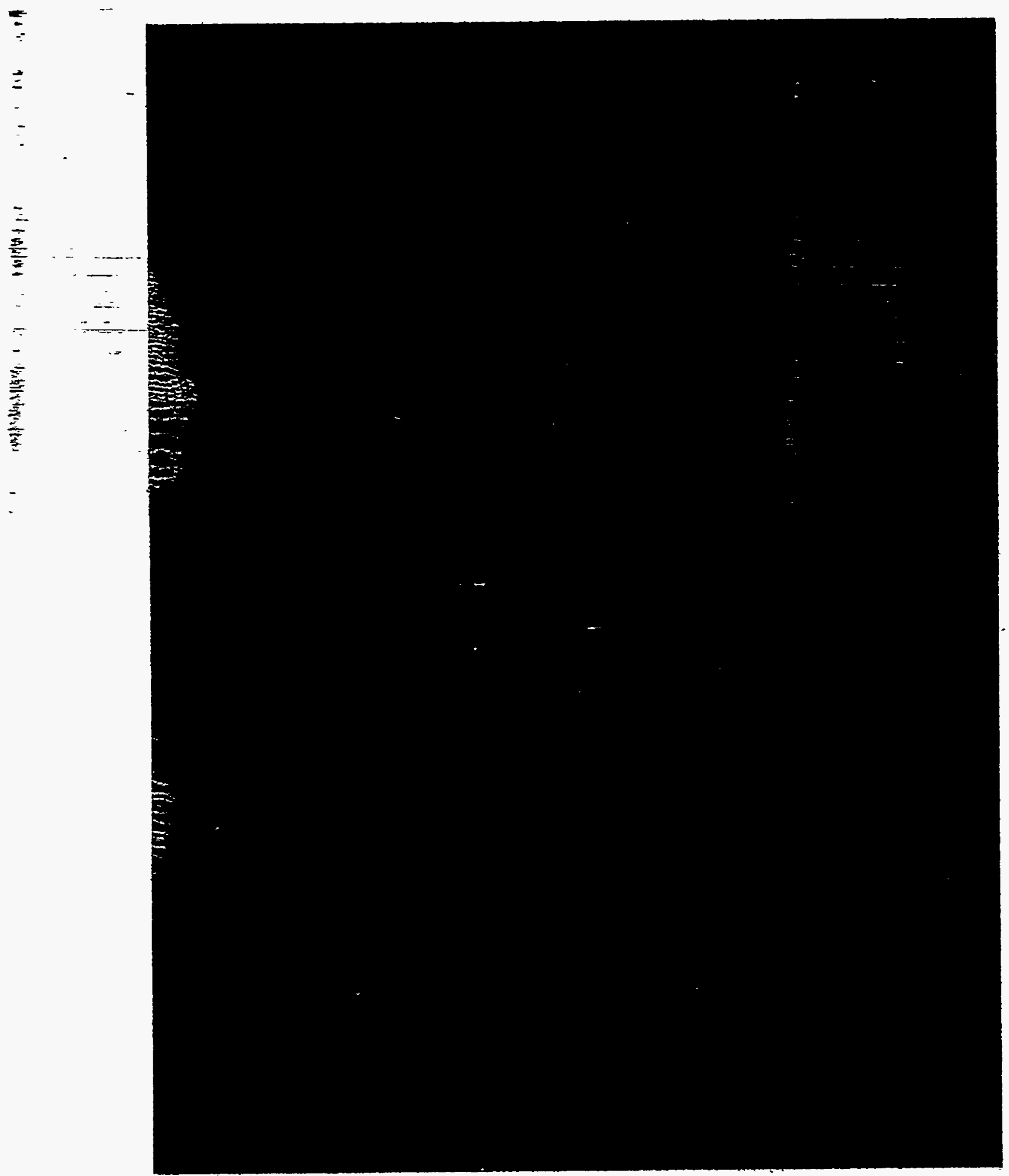

Figure 3. Metaphase chromosomal spread viewed by Feulgen fluorescence. Cycloheximide treated; see Figures 4 \& 5 for measurements. 


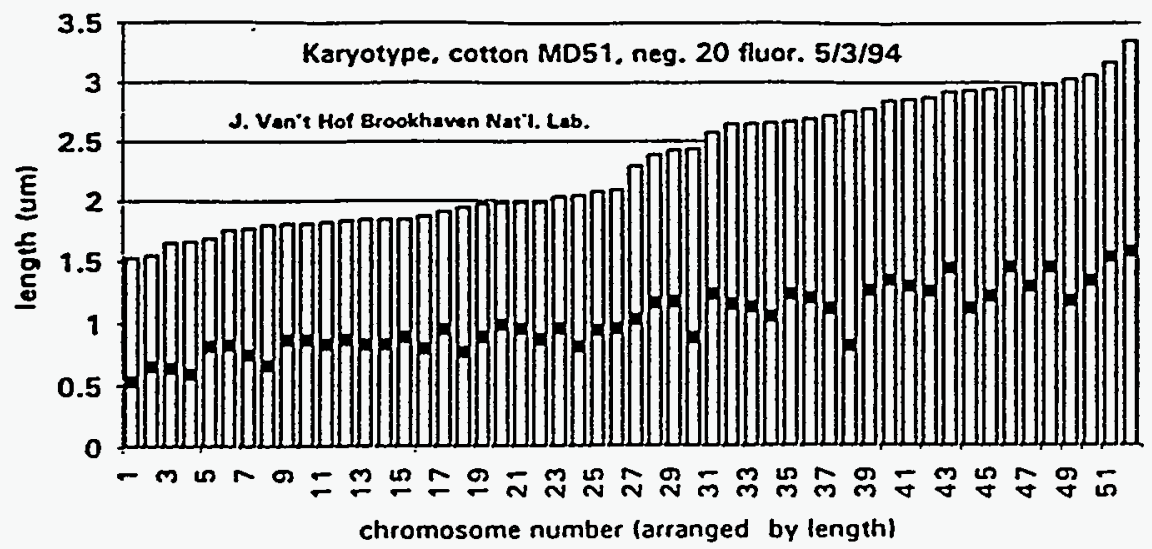

Figure 4. Chromosomes shown in Figure 3 arranged by length. Black squares show centromere position.

Karyotype, cotton MD51, neg. 20 fluor.. 5/3/94

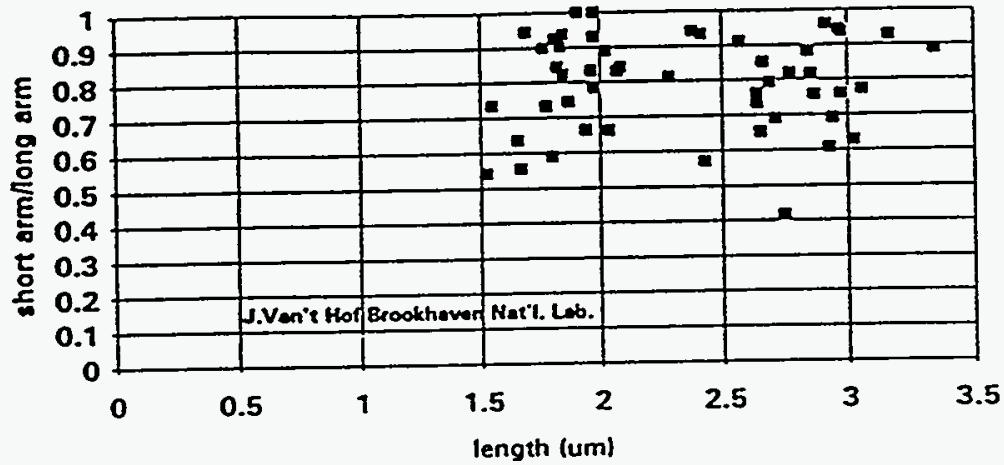

Figure 5. The ratio of short arm to long arm length of each chromosome expressed as a function of its total length. Note the two clusters of datum points. 
c. Intensified stain with toluidine blue; can be used for squash and protoplast spreads

1. toluidine blue solution is:

$$
\begin{aligned}
& 0.05 \% \text { toluidine blue } \\
& 0.1 \mathrm{M} \text { citric acid } \\
& 0.2 \mathrm{M} \mathrm{Na} \mathrm{NPO}_{4}, \mathrm{pH} 6.8
\end{aligned}
$$

Mix and filter before use; store at room temp.

2. streak about $25 \mathrm{ul}$ of stain at 90 degrees to the length of the microscope slide

3. carefully spread stain over cells using the edge of a coverslip; make sure the edge of the coverslip does not touch the surface of the slide

4. add drop of $100 \%$ glycerol to center of stain

5. place coverslip over glycerol drop, cells \& stain

6. blot to remove excess stain, glycerol, etc.

7. see Figure 6 for toluidine-stained chromosomal complement and Figure 7 for measurements 


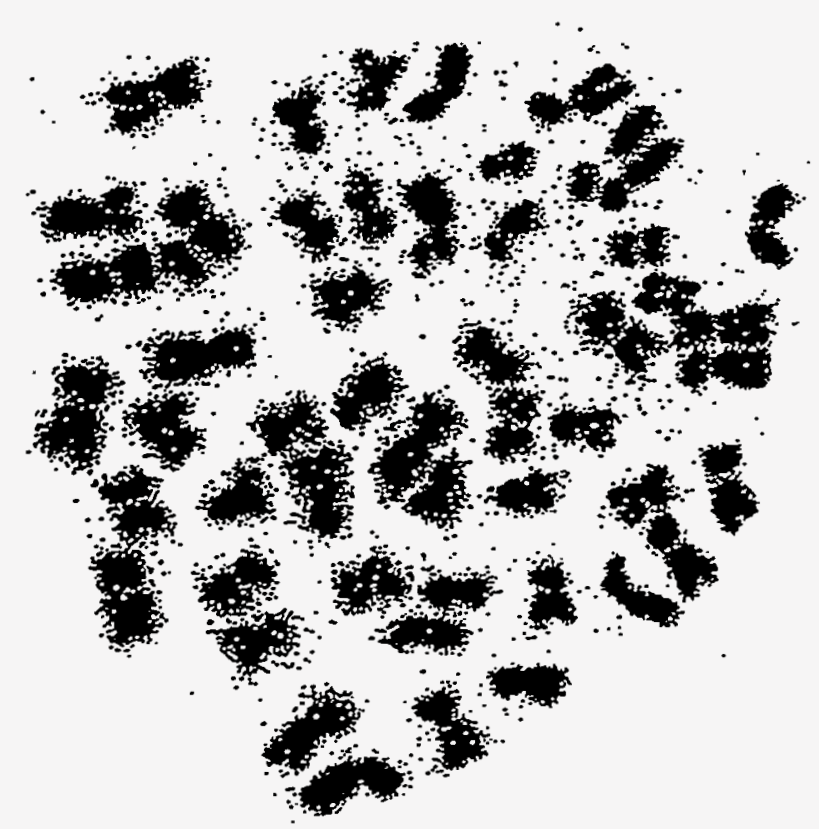

Figure 6. Chromosomal spread from protoplast stained by the Feulgen method and enhanced with toluidine blue. Cycloheximide treated.

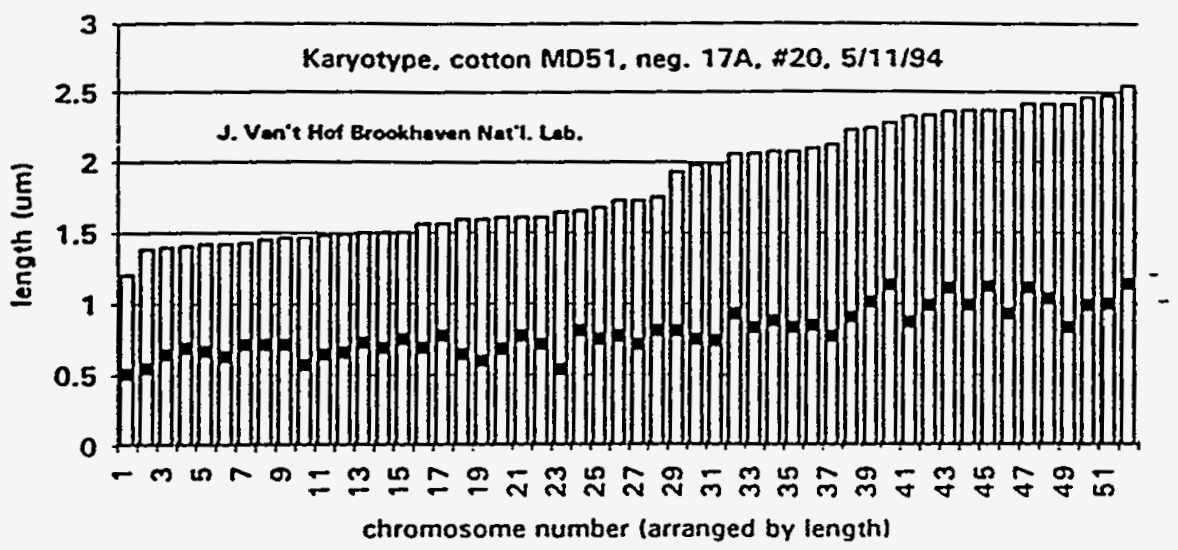

Figure 7. Chromosomes shown in Figure 6 and on cover arranged by length. Black squares show centromere position. 
VI. In situ hybridization; preliminary results

A. Separation of cells

1. remove 6 root tips from fix \& cut off $2-3 \mathrm{~mm}$ tips

2. suspend tips in ice-cold, sterile-filtered citrate buffer in $1.5 \mathrm{ml}$ Eppendorf tube; spin for $2 \mathrm{sec}$. in microfuge

$$
\begin{aligned}
& \text { citrate buffer is: } \\
& 0.01 \mathrm{M} \text { Na-citrate } \\
& 0.01 \mathrm{M} \text { citric acid titrated to } \mathrm{pH} 4.6
\end{aligned}
$$

3. wash with 3 changes of citrate buffer

4. remove buffer

5. add $100 \mathrm{ul}$ of sterile-filtered enzyme

a. can be the mix of three enzymes mentioned on page $(0.01 \mathrm{gm}$ of $3: 1: 1 \mathrm{mix}$ in 100 ul of citrate buffer pH 4.6$)$ or

b. $2 \%$ pectolyase in citrate buffer, $\mathrm{pH} 4.6$

6. digest for $30 \mathrm{~min}$ at $37 \mathrm{C}$

7. break-up root tips with micropipet tip

8. continue digestion for another $30 \mathrm{~min}$

9. spin at $2300 \mathrm{rpm}(800 \times \mathrm{g})$ in TJ-6 centrifuge for 4 min

10. remove ALL BUT 1 MM of supernatant

11. add $200 \mathrm{ul}$ of ice-cold citric acid buffer, vortex

12. spin at $2400 \mathrm{rpm}$ in $T J-6$ for $4 \mathrm{~min}$

13. repeat "11" \& "12" above

14. again repeat " 11 " \& " 12 " above

15. remove ALL BUT I MM of supernatant

16. add about 200 ul of ice-cold $3: 1 \mathrm{fix}$

17. suspend cells by vortexing, spin as in \#12 above

18. repeat \#15,16 and 17 above, twice using 100 ul of fix on last spin

19. place on ice

B. Spreading cells on microscopy slides

1. rub 3:1 fix on surface of acid-cleaned slide

2. resuspend cells

3. remove 5 ul with micropipet

4. place tip on slide and slowly dispense 5 ul on its surface

5. air dry

6. check preparation by phase microscopy

7. store slides in box at $-20 \mathrm{C}$ until ready to use 
C. In situ hybridization; squash preparations; VERY PRELIMINARY RESULTS!

1. transfer fixed root tips to $1.5 \mathrm{ml}$ Eppendorf tube

2. add $1 \mathrm{ml}$ deionized water and let stand at room temp. for $5 \mathrm{~min}$

3. spin in microfuge for a second or two and remove water

4. add $1 \mathrm{ml}$ of deionized water and spin again

5. repeat \#4 twice

6. add $200 \mathrm{ul}$ of triple enzyme mix (page 6) dissolved in deionized water

7. incubate at room temp. for $30 \mathrm{~min}$; tap side of tube occasionally

8. spin and remove enzyme solution

9. add deionized water and spin; repeat once again

10. add deionized water and place on ice

11. carefully remove root tips (they stick to each other) and place on squeaky clean slide

12. add 4 ul of $45 \%$ acetic acid and macerate with glass rod; spread tissue on slide surface by tapping perpendicular to surface of slide

13. place coverslip over macerated tissue

14. blot between absorbent paper; do not move coverslip

15. press with thumb or finger taking care the coverslip will not move

16. place on dry ice; leave for 3-5 min

17. "pop off" coverslip by prying edge with a razor blade

18. place in $95 \%$ ETOH; leave overnight

19. air dry

20. place about $100 \mathrm{ul}$ of RNAse $(100 \mathrm{ug} / \mathrm{ml})$ on cells, cover with coverslip and incubate 1 hour at $37 \mathrm{C}$ in moist chamber

21. float off coverslip in $2 \mathrm{X}$ SSC and rinse with $2 \mathrm{X}$ SSC

22. dehydrate through ETOH series $(50 \% \rightarrow 70 \% \rightarrow 95 \% \rightarrow$ air dry)

23. add 20 - 30 ul of probe mix:

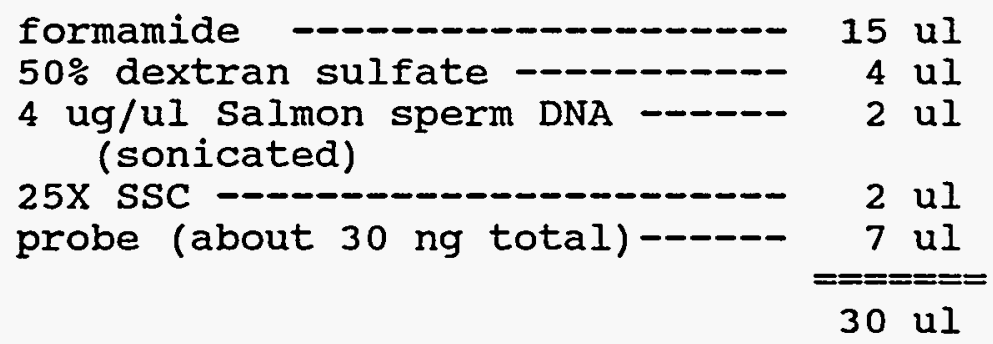

24. cover with silicon coated coverslip and heat $10 \mathrm{~min}$ at $80 \mathrm{C}$ on heated aluminum block

25. seal with rubber cement

26. incubate at $37 \mathrm{C}$ overnight in moist chamber

27. submerge slide in $2 X$ SSC and remove coverslip

28. rinse in $2 \mathrm{X} \mathrm{SSC} 5 \mathrm{~min}$ 
29. incubate in $50 \%$ formamide-50\% $2 \mathrm{XSSC}$ for $15 \mathrm{~min}$ at $37 \mathrm{C}$

30. repeat \# 29 with fresh formamide/2x SSC mix

31. wash in $2 \mathrm{X}$ SSC $15 \mathrm{~min}$ at room temp.

32. remove slide leaving the surface of cells wetted

33. add a small drop of $100 \%$ glycerol, cover with coverslip

34. blot to remove excess glycerol, etc

35. view by fluorescence microscopy; see Figure 8 for result

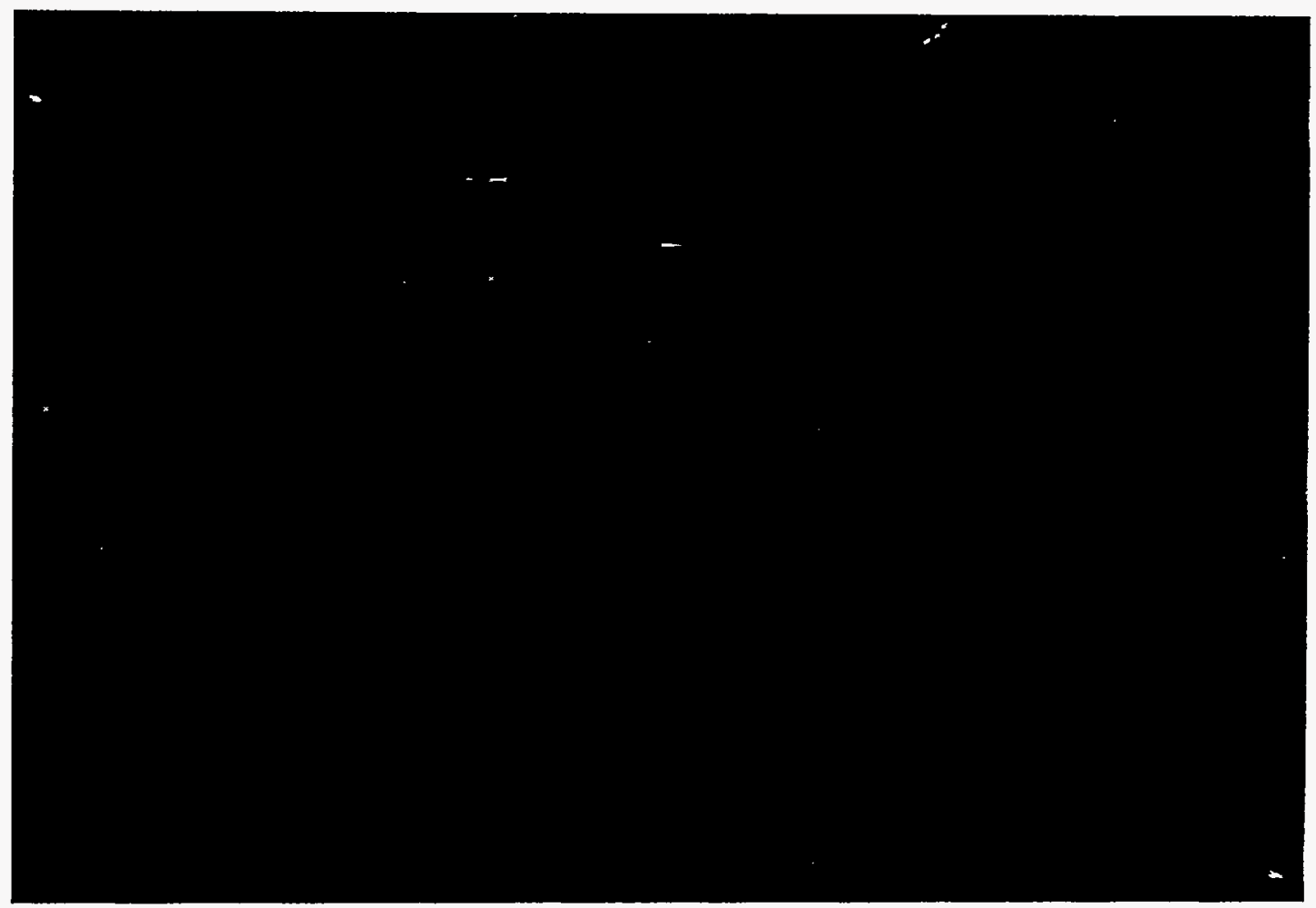

Figure 8. Hybridization of rDNA fluorescent probe to squash preparation. The six spots correspond to the six known loci of the rRNA genes expected in a somatic chromosomal complement. No image enhancement used. 


\section{References:}

1. Hadder; J. C. and Wilson, G. B. Cytological assay of Cmitotic and prophase poison actions. Chromosoma 9: 91 - 104, 1958 .

- actidione=cycloheximide effect

2. Smith, H. H., Fussell, C. P. and Kugelman, B. H. Partial synchronization of nuclear divisions in root meristems with 5-aminouracil. Science 142: 595 - 596, 1963.

- 5-aminouracil

3. Prensky, W. and Smith, H. H. The mechanism of 5-aminouracilinduced synchrony of cell division in Vicia faba root meristems. J. Cell Biology 24: $401-414,1965$.

- 5-aminouracil

4. Van't Hof, J. Experimental Procedures for Measuring Cell Population Kinetic Parameters in Plant Root Meristems, in Methods in Cell Physiology, D. M. Prescott, ed., pp. 95 117, Academic Press, New York (1968).

- Hoagland's nutrient solution and other information

5. Van't Hof, J. DNA fiber replication of chromosomes of pea root cells terminating S. Exp. Cell Res. 99: 47 - 56, 1976. - cycloheximide treatment

6. Van't Hof, J. and Lamm, s. S. Site of initiation of replication of the ribosomal genes of pea (Pisum sativum) detected by two-dimensional gel electrophoresis. Plant Molecular Biology 20: 377-382, 1992.

- cell synchrony curve of pea

Copies sent to:

Dr. Hal L. Lewis

Scientifc seed Company

Lewis Farm

P.O. Box 268, Hwy 181 So.

Dell, Arkansas 72426

Prof. William R. Meredith, Jr. USDA, ARS

Cotton Physiology \& Genetics Unit P.O. Box 345

Stoneville, Mississippi 38776

Prof. Harold J. Price

Soil \& Crop Sciences Department

Texas A \& M University

College station, Texas 77843

Prof. Si Saha

Department of Plant \& Soil Sciences

Alabama A \& M University

Normal, Alabama 
Prof. R. W. Seagull

Plant and Cell Physiology

114 Hofstra University

Hempstead, New York 11550-1090 